\title{
The Influence of Beef Cattle Breeder Characteristic on the Business Scale of Bumi Karomah Breeders Group in the City of Probolinggo
}

\author{
Anggraeny YN, Prita KS, Mariyono \\ Indonesian Beef Cattle Research Station \\ Jl. Pahlawan No. 2, Grati, Pasuruan 67184, East Java, Indonesia \\ yennysahim@gmail.com
}

\begin{abstract}
This research aims to know the influence of the farmer breeder characteristics on the business scale which measured by livestock number owned. This research was conducted in the city of Probolinggo, East Java. The respondents in this study included beef cattle farmer breeders who are the active members of Bumi Karomah group. The number of respondents were 30 peoples. Data were collected through interviews using a questionnaire. Data in this research were analyzed using multiple regression analysis to test the influence of beef cattle farmer breeder characteristics on business scale. Multiple linear regression analysis result showed that age, number of family burden and cattle raising experience do not affect significantly to business scale owned by farmer breeders with determination coefficient $17 \%$ means that the characteristics of breeders on in family burden variables affects the number of business scale only by $17 \%$, and the rest is affected by other variables. Meaning, that the diversity of the three characteristics of the breeder are not strong enough to explain the diversity of the business scale.
\end{abstract}

Key Words: Farmer Breeders Characteristics, Beef Cattle, Business Scale

\section{INTRODUCTION}

The increasing of population growth in Indonesia results in increasing need of beef as one of animal protein sources. Therefore, in Indonesia the beef cattle breeding sector is one of breeding sectors that has good prospect. The development of beef cattle breeding business in Indonesia is generally conducted in two forms, namely the small dairy farms and beef cattle breeding corporations. Citizen breeding businesses in Indonesia give big contribution in providing animal protein source for Indonesian citizens therefore the productivity of the livestock especially ruminant need to be increased to fulfill the need of meat. The management of dairy farms owned by citizen is conducted by breeders as well as labor in the breeding company. Breeders and labor are human resources that directly involved in the activities of the breeding subsector. Effort to increase the revenue of the breeders by improving the beef cattle business owned by citizen need a right and appropriate technology so that it is expected to increase the need of labor, the breeders will earn optimal profit and the welfare of the breeders can be realized. The beef cattle business said to be successful when breeders have contributed income and fulfilled life expense of the breeders and their family, this can be seen fromcattle weight growth, growing number of livestock ownership, and also increasing in household income. According to Abidin (2002), the management and raising of beef cattle is one of the ways to improve breeders' household income. To increase the breeders' household income, a breeding improvement program is needed, in building sustainable beef cattle breeding improvement program, a review of beef cattle production system as well as the obstacles and purpose are needed (Musa et al. 2006). Probolinggo city, which is located in the coast of East Java Province, is one of the cities that develop beef cattle. And the Probolinggo City Government has seriousness in developing the beef cattle through the livestock groups, one of the groups that already formed namely Bumi Karomah Fattening Livestock Group. Farmers in 
Indonesia generally still use traditional farming systems because the scale of business ownership is relatively small. Many factors affect the number of animals kept ownership of farmers. Characteristics of farmers is one of the causes that affect the amount of business scale kept by breeders. From the description above, in this study will discuss the characteristics of farmers (internal factors) that influence the amount of business scale farmers.

\section{MATERIAL AND METHODS}

\section{Place and time of the study}

The location of the research was in the group of Bumi Karomah Beef Cattle Fattening in Probolinggo City, East Java Province. The research was conducted in July to December 2015.

\section{Method of data collection}

The data collection was conducted by survey method. The collected data included the primary and secondary data. Primary data was obtained by direct interview with the respondents. The sampling collection technique which used is a purposive sampling technique that is sampling collection based on certain consideration namely the beef cattle fattening breeders who are the members of the Bumi Karomah breeders group by using questionnaire that has been prepared. The number of respondents were 30 farmers. The observed variables were characteristics of breeders including age, number of family burden, breeding experience, and business scale owned by the breeders. The data analysis used multiple linear regression analysis according to Sugiono (2005). This multiple linear regression analysis is used to know the influence of breeders characteristics against the business scale owned by the breeders, by using the formula:

$$
Y=a+b_{1} X_{1}+b_{2} X_{2}+b_{3} X_{3}
$$

$\begin{array}{ll}\mathrm{Y} & : \text { Business scale of breeders } \\ \mathrm{a} & : \text { Y-intercept } \\ \mathrm{b}_{1}, \mathrm{~b}_{2}, \mathrm{~b}_{3} & : \text { Regression coefficient } \\ \mathrm{X}_{1} & : \text { The number of family burden } \\ \mathrm{X}_{2} & : \text { The age of breeders } \\ \mathrm{X}_{3} & : \text { The breeding experience }\end{array}$

\section{RESULTS AND DISCUSSION}

\section{The characteristic of the respondent breeders}

Breeding development business is inseparable from the breeders therefore the characteristics of breeders areneededto determine the future pattern of beef cattle breeding development. The general overview of the Bumi Karomah Breeding Group breeder characteristicsis presented in Table 1 .

\section{The age of respondent farmer breeder on}

The research results showed productive age group or 20-50 years old is as many as 25 people $(83.3 \%)$ and non-productive age group or $>50$ years old is as many as five people $(16.7 \%)$. Based on percentage results, most farmer breeders are in the productive age. The 
Table 1. The farmer characteristics of Bumi Karomah Group

\begin{tabular}{lcc}
\hline \hline Farmer characteristics & Number of respondens & Persentage $(\%)$ \\
\hline Age & 25 & 83.3 \\
20-50 years old & 5 & 16.7 \\
$>51$ years old & & \\
Experience of cattle raising & 15 & 50.0 \\
$\quad<11$ years & 4 & 13.3 \\
11-21 years & 11 & 36.7 \\
$>22$ years & & \\
Family burden & 13 & 43.3 \\
1-3 of persons & 16 & 53.4 \\
$>3-6$ of persons & 1 & 3.3 \\
$>6$ of persons & & \\
\hline
\end{tabular}

large number of farmer breeders in productive age is the main capital in the development of breeding business, because the breeders' age is one factor that affects work and mindset of the breeders themselves in determining business technique which applied in cattle raising pattern. According to Chamdi (2003), the farmer breeders with productive age or between 20-45 years old have high spirits and easy to adopt new things. It is different with older farmer breeders (>50 years old). Even according to Soekartawi (2003) the age of farmers who are still young usually have a high motivation. Young farmers want to know what is not known, so that farmers who are still young will try to absorb new information to increase knowledge of farming that is expected to increase the number of animals maintained. In line with expressed by Soekartawi (2003) that older age group tend to be fanatical in tradition and difficult to be given an understanding that can change the pattern of life, way of working, and their mindset. However, the older the farmer breeders the higher experience they have (Suratiyah 2006). Beside that, the age of farmers gives maturity in many ways are psychologically, socially, physically, and economically. And It is associated with social status, wisdom and control of resources of labour, land, capital and also including risk taking.

\section{Experience of cattle raising}

The cattle raising experience consists of $50 \%$ low experience category, $36.7 \%$ or 11 peoples in high experience category, and $13.3 \%$ or four people in medium category.

This is in accordance with Murwanto (2008) who suggested that beef cattle raising experience is variable which plays a big role in determining the success of breeders in improving their cattle livestock business development as well as effort to increase the income of the breeders. Cattle raising experience is a good teacher, with enough experience in cattle raising cattle the breeders will be more constentious in running their business and improving their past disadvantages. But have a long experience of breeding beef cattle farmers do not make it will increase the number of business scale maintained by the breeder, but farmers who have long experience of breeding is proportional to the age of the farmers, the longer farmer experience cattle raising, the farmers is getting older too. So have a long experience of breeding beef cattle farmers do not make it will increase the number of business scale maintained by the breeder. 


\section{The number of family burden}

The research results in Bumi Karomah group in the City of Probolinggo indicates the number of breeders' family burden is ranged from four to six people (Table 1) therefore farmer breeders are required to work to fulfill their family's daily need. The number of farmer breeders' family burden can affect the activity of the farmer breeders business because the family members can supply available manpower in raising their cattle, according to Soekartawi et al. (1986) higher number of family members can be burden to the family, but on the other hand also can be a source of workforce. The failure of the breeders in their breeding activities would be very influential towards the fulfillment of their family life need. Hasyim (2006), the number of family farmers was a factor that naccessary to be attended on determining income in fulfiling demand. The number of family farmers can stimulate the farmer for carrying out many activities especially for finding ways to increase farmers' income (Makalew et al. 2013). The greater number of family burden, the greater the cost of living to be incurred by the farmer, so that the proceeds from the sale of livestock used for subsistence, although on the other side, farmers breeder need cost to increase the scale of business.

\section{Business scale}

Business scale of livestock ownership, based on the result of the research, indicates that the number of cattle owned by breeders ranged from one to three cattles with the average number is 2.1 cattle/breeder. The low average number of livestock ownership indicates that breeders in managing their business are still using the traditional way and not serious enough, only doing it as side business, therefore the number of the cattle owned is also very low. The higher or the lower number of the breeders ownerships also contributes in giving additional income and fulfillment of breeders' family life. In accordance with the opinion of the Paturochman (2005) which suggested that the livestock ownership business scale is very influential towards the income levels, therefore, the bigger business scale of livestock ownership the greater income level of the breeders.

Table 2. The number of business scale

\begin{tabular}{lcc}
\hline \hline Number of cattle ownership & Number of repondents & Persentage (\%) \\
\hline $1-3$ & 27 & 90 \\
$4-6$ & 3 & 10 \\
\hline Total number & 30 & 100 \\
\hline
\end{tabular}

Source: The results of data processing, 2015

\section{The analysis of the relationship between breeder characteristics against breeder business scale}

The result of multiple linear analysis showed relationship between business scale owned by breeders with the number of family burden, breeders age, and breeding experience with equation $\mathrm{Y}=2.445+0.101 \mathrm{X}_{1}+0.001 \mathrm{X}_{2}+0.007 \mathrm{X}_{3}$. with the determination coefficient of $17 \%$, shows that three infamily burden variables in the study influence and have relationship between the characteristics of the breeder (breeder age, number of family burden, andbreeding experience) with the business scale owned by breeders by $17 \%$, the remaining $83 \%$ is affected by other variables. That is, this multiple 
regression equation, with this three independent variables are not enough yet to estimate the scale level of breeding farm.

\section{The number of family burden $\left(\mathrm{X}_{1}\right)$}

The analytical result of family burden number in this research showed $\mathrm{P}>0.05$ that indicates there is no significant influence on business scale owned by breeders. The number of family burden is associated with the supply of workforces who are used for livestock fattening business. According to Tatipikalawan (2012), the small-scale breeding business will use workforce from family and does not require specific skills. Therefore, the family member does not affect the business scale owned by the breeders.

\section{The age of farmer breeders $\left(X_{2}\right)$}

The analytical result in this research of the breeders age showed $\mathrm{P}>0.05$ that indicates there is no significant influence on the business scale owned by the breeders. The average age of the breeders is 45 years old which is in the range of productive age. According to Prabayanti (2010), people in productive age generally have high spirits to know the latest information. Therefore, the breeders in their productive age are expected to be able to increase the number of their business scale in the future, but not in this research yet.

\section{The cattle raising experience $\left(\mathbf{X}_{3}\right)$}

The analytical result of the breeding experience in this research showed value of $\mathrm{P}>0.05$ which means there is no significant effect to the business scale of the breeders. The breeders have enough experience in breeding the cattle, but the raising method still monotonous and traditional therefore it is not in line with the business condition of beef cattle fattening, in accordance with the opinion of Tatipikalawan (2012) that breeders with enough experience but do not have motivation, management knowledge, and capital will not be able to expand their breeding business.

\section{CONCLUSION}

Based on the analysis, the result obtained is the number of family burden family (X1), the age of the breeders (X2), and the breeding experience (X3) have no significant effect on the business scale (Y) that owned by the breeders of Bumi Karomah Group in Probolinggo City.

\section{REFERENCES}

Abidin Z. 2002. Penggemukan Sapi Potong. Jakarta (Indonesia): PT Agro Media Pustaka.

Chamdi AN. 2003. Kajian profil sosial ekonomi usaha kambing di Kecamatan Kradenan, Kabupaten Grobongan. Dalam: Mathius IW, Setiadi B, Sinurat AP, Ashari, Darmono, Wiyono A, Purwadaria P, Murdiati TB, penyunting. IPTEK untuk Menyejahterakan Petani melalui Agribisnis Peternakan yang Berdaya Saing. Prosiding Seminar Nasional Teknologi Peternakan dan Veteriner. Bogor, 29-30 September 2003. Bogor (Indonesia): Puslitbangnak. hlm. 312-317. 
Hasyim H. 2006. Analisis hubungan karakteristik petani kopi terhadap pendapatan (studi kasus Desa Dolok Saribu, Kecamatan Paguran, Kabupaten Tapanuli Utara). J Komunikasi Penelitian. 18:2006.

Makalew J, Kusuma Z, Sugiyanto, Tamod Z. 2013. The influence of farmer characteristic and farming to the farmer motivation on using organic manure (case study in East Tombatu District, South-East Minahasa Regency). Int J Eng Invent. 3:43-51.

Murwanto AG. 2008. Karakteristik peternak dan tingkat masukan teknologi peternakan sapi potong di Lembah Prafi Kabupaten Manokwari. J Ilmu Peternakan. 3:8-15.

Musa M, Peters KJ, Ahmed MKA. 2006. On farm characterization of Butana and Kenana cattle breed production systems in Sudan. Livest Res Rur Dev. 18:2006.

Paturochman M. 2005. Hubungan antara tingkat pendapatan keluarga peternak dengan tingkat konsumsi (kasus di Koperasi Peternakan Bandung Selatan (KBPS) Pangalengan). Sosiohumaniora.7:2005.

Prabayanti H. 2010. Faktor-faktor yang mempengaruhi biopestisida oleh petani di Kecamatan Mojogedang Kabupaten Karanganyar [Skripsi]. [Surakarta (Indonesia)]: Universitas Sebelas Maret.

Soekartawi. 2003. Teori ekonomi produksi (dengan pokok bahasan analisis fungsi produksi CobbDouglas). Jakarta (Indonesia); Rajawali. hlm. 7-8.

Soekartawi, Suhardjono, Hartono T, Ansjarullah A. 1986. Rancangan instruksional. Jakarta (Indonesia): PT Rajawali Press.

Suratiyah K. 2006. Ilmu usahatani. Jakarta (Indonesia): Penebar Swadaya.

Sugiyono. 2005. Statistik untuk penelitian. Bandung (Indonesia): CV Alfabeta.

Tatipikalawan JM. 2012. Analisis produktivitas tenaga kerja keluarga pada usaha peternakan kerbau di Pulau Moa Kabupaten Maluku Barat Daya. J Agroforestri. 7:8-15. 